\title{
The Fossil Tabanids (Diptera Tabanidae): When They Began to Appreciate Warm Blood and When They Began Transmit Diseases?
}

\author{
Rafael Gioia Martins-Neto
}

\author{
Sociedade Brasileira de Paleoartropodologia, Universidade Guarulhos, Rua Arnaldo Vitaliano 150, apto 81, 14091-220 \\ Ribeirão Preto, SP, Brasil
}

A discussion of the known fossil tabanids (Diptera Tabanidae) is presented based on fossil evidence. This includes the origin of the hemathophagy in the Brachycera, more specifically for tabanids. Several tabanid species in the extant fauna are vectors for disease-producing organisms that affect humans and animals. Bacteria, viruses, rickettsiae, protozoa, and filarial worms can be transmitted by them, causing such diseases as anthrax, tularemia, anaplasmosis, various forms of trypanosomiasis, $Q$ fever, and filariasis. However, if tabanids are directly responsible for all of these diseases is not consensual and the known fossil evidence is presented here.

Key words: Diptera - fossil Tabanidae - paleoparasitology - blood-suckers evolution - diseases in the past

The bloodsucking insects of the orthorraphous families of Diptera are known from the Early Cretaceous and include Psychodida, Corethrellidae, Culicidae (with some doubts), Ceratopogonidae, Simuliidae, Rhagionidae, Tabanidae, and Athericidae (Ansorge 1994, Lukashevich \& Mostovski et al. 2001).

Although brachycerous flies are abundant in the fossil record, with several families recorded (Apystomyiidae, Archocyrtidae, Asilidae, Eremochaetidae, Hilarimorphidae, Kovalevisargidae, Mythicomyiidae, Nemestridae, Protapioceridae, Raghionempididae, Empididae, Scenopinidae, Stratyomyidae, Therevidae, Vermileonidae, Xylomyidae, and Xylophagidae), since the Middle Jurassic (Mostovski 1998), tabanids are relatively scarce in the fossil record (mainly in Mesozoic).

The older record of a true tabanid came from the Upper Jurassic deposits of China (Ren 1998), with three genera and three species, all related to the flower feeders, Pangoniinae. The Cretaceous record comprises specimens from the Lower Cretaceous of England (Coram et al. 1995) and Spain (Lukashevich \& Mostovski 2001), and a possible specimen in the Cretaceous of South Africa (Mostovski 1998). For the Cenozoic, the following named species are known: from the Miocene of Florissant, Colorado, respectively named Tabanus parahippi Cockerell 1909, Tabanus hipparionis Cockerell 1909, and Tabanus merychippi Cockerell 1917; from the North American Oligocene, Silvius merychippi Melander 1947; from the Germany Oligocene, Tabanus statzi Moucha 1972; from the French Olicocene, Aemodipsus bornensis Maneval 1936 and Chrysops seguyi Piton 1940; from the Swittzerland Oligocene, Hexatoma oeningensis (Herr 1864) Evenhuis 1994, and Tabanus vectensis Cockerell 1921, for the En-

Fax: +55-16-624.2884. E-mail: martinsneto@terra.com.br Received 26 August 2002

Accepted 25 November 2002 gland Eocene/Oligocene. From the Baltic amber (Eocene/ Oligocene), Stenotabanus brodzinskyi Lane, Poinar \& Fairchild 1988 and Stenotabanus woodruffi Fairchild \& Lane 1989. Tabanidae were also found in Oligocene inclusions from Chiapas, Mexico (Morales \& Pimentel 2001). For the Pliocene from Poland, Europe, North Africa and Morocco the species Tabanus sudeticus Zeller 1842 was recorded.

An unnamed species was assigned to the genus by Grabenhorst 1985, for the German Pliocene. Scudder (1895) recorded a possible new genus and species of tabanid from the Miocene Oeningen deposits of Switzerland. Undescribed Tabanidae have been noted from the Eocene of the Green River Formation (Bradley 1931, Swanson \& Lewis 1993). The Cretaceous genus Protabanus, described by Hong (1982) has been shown by Grimaldi (1990) and Zhang (1993) to belong to the order Homoptera, where it has been placed in the cicadoid family Tettigarctidae by Hamilton (1992) in his catalog of Mesozoic Homoptera genera (see also Evenhuis 1994). The species of Haematopota described by Stuckenberg (Haematopota pinicola Stuckenberg 1975) as from Baltic amber has been shown by Lewis et al. (1977) to actually be a copal inclusion from an unknown locality in Africa. An older undetermined compression fossil of Tabanidae from the Middle Jurassic Mont-Saint-Marin deposit in Luxemburg was noted by Maurice (1882). There are Cretaceous genera described by Kovalev (1986) from Mongolia, but are treated by Evenhuis (1994) as unplaced in Tabanoidea.

\section{THE BRAZILIAN FOSSIL DIPTEROFAUNA}

The presently known Brazilian dipterofauna came just from three localities: Santana Formation (Lower Cretaceous, Northeast Brazil), Tremembé Formation and EntreCórregos Formation (both Oligocene, Southeast Brazil).

From the Santana Formation the following Diptera groups are known: Chironomoidea (unpublished material, Fig. 1A), Asilidae, (Grimaldi 1990, and further unpublished material - Fig. 1B), Bibiomorpha (unpublished material Fig. 1A), Tipulidae (Ribeiro \& Martins-Neto 1999, Ribeiro 
\& Krzeminski 2000), Simuliidae (Vulcano 1985). For the purposes of this contribution it is irrelevant if the Vulcano's brief communication has serious problems with the International Zoological Nomenclatural Code. Of course, it is another nomina nuda in the paleontological literature, because this specimen never receive a systematic treatment. Fortunately I saw this specimen myself and I can confirm that it is a true female simuliid, the oldest known record of a Diptera Simuliidae), and Tabanidae, Cratotabanus stonemyomorphus Martins-Neto \& Santos 1994 (Fig. 2).

From the Tremembé Formation, Taubaté Basin, Oligocene of the State of São Paulo, are known the following groups: Hybotidae, Mycetophilidae, Diastatidae, Empididae (Fig. 1C), Tipulidae and Tabanidae (MartinsNeto 1997, 1999a, b, Martins-Neto et al. 1992), with the named species Tabanus? tremembeensis MartinsNeto1997 (Fig. 3).

A

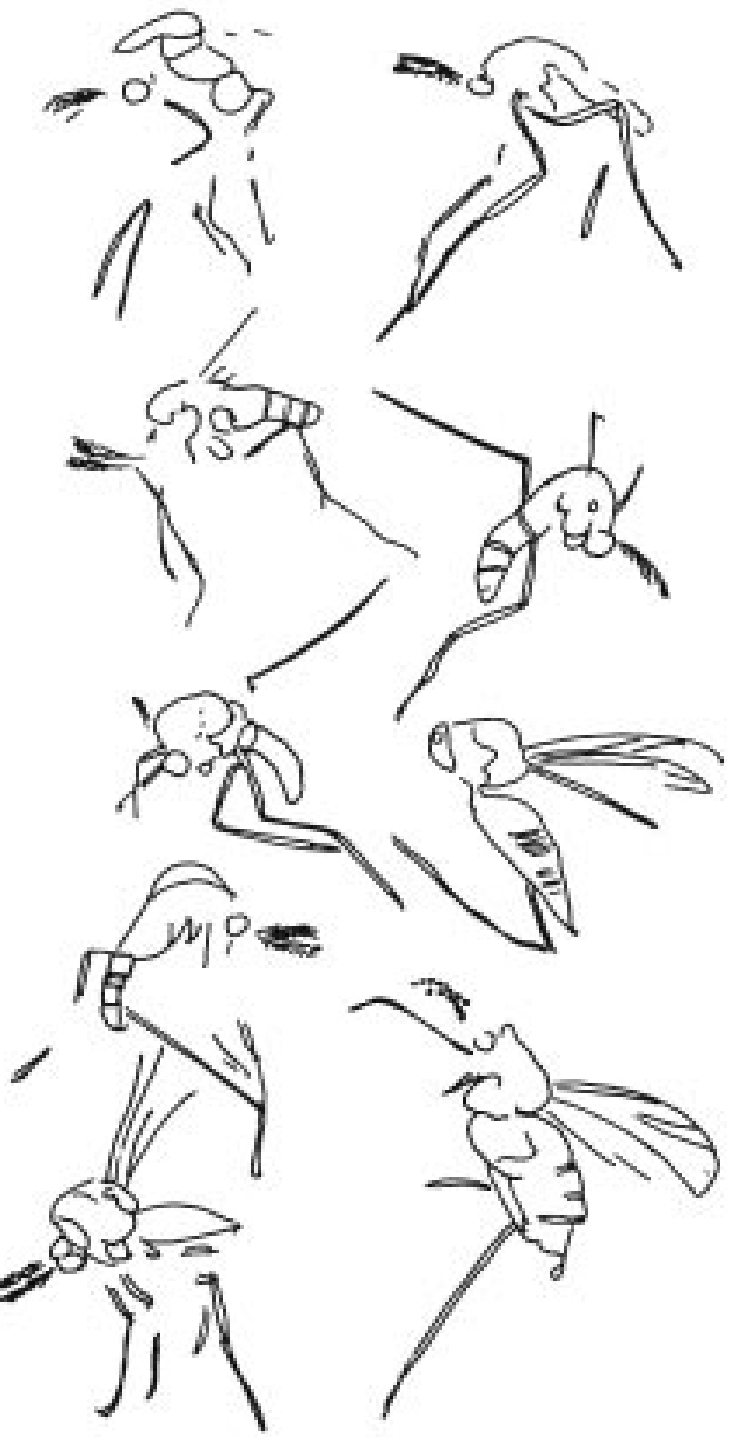

From the Entre-Córregos Formation, Aiuruoca, Oligocene of the State of Minas Gerais, just a Mycetophilidae species is known.

Grimaldi (1990) illustrates a dipteran specimen, interpreted as a Therevidae indet. (Fig. 2D), from the Santana Formation, but this specimen needs be moved to the genus Cratotabanus Martins-Neto \& Santos (1994), constituting a new species of Tabanidae for these deposits (the second one).

\section{THE BLOODSUCKING TABANIDS. WHEN DID THEY} BEGIN?

Most adult female Tabanidae, in the extant fauna, feed on blood of warm-blooded animals, but a few species are known to attack cold-blooded vertebrates (Pechuman \& Teskey 1981), and several species are not hemathophagous. These, as well as the females that are blood feeders, and males that are not hematophagous, are known
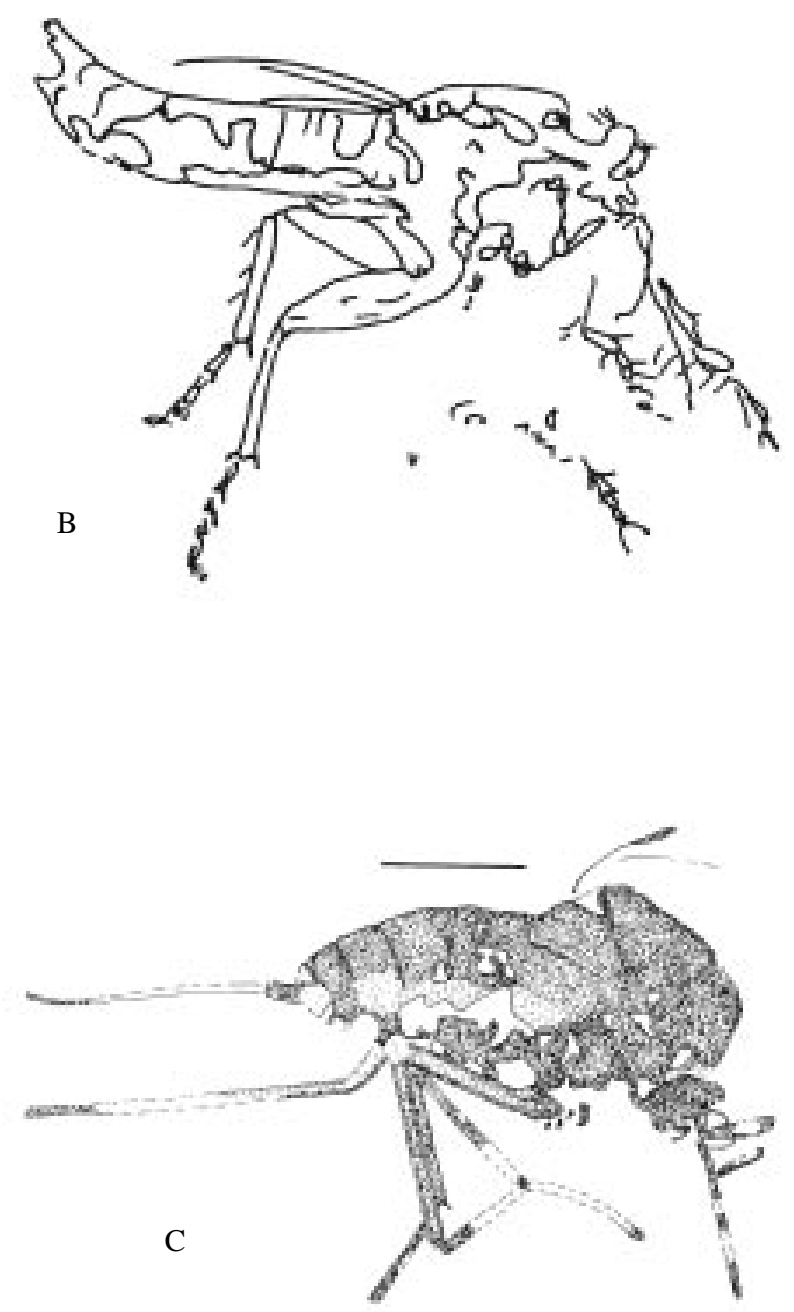

Fig. 1-A: unpublished Chrinomoidea and Bibiomorpha from the Santana Formation (Lower Cretaceous, Northeast Brazil); B: unpublished Asilidae from the Santana Formation; C: Taubatempis trompetilia Martins-Neto, reproduced of Martins-Neto (1999b), Empididae from Tremembé Formation (Oligocene of the State of São Paulo). 

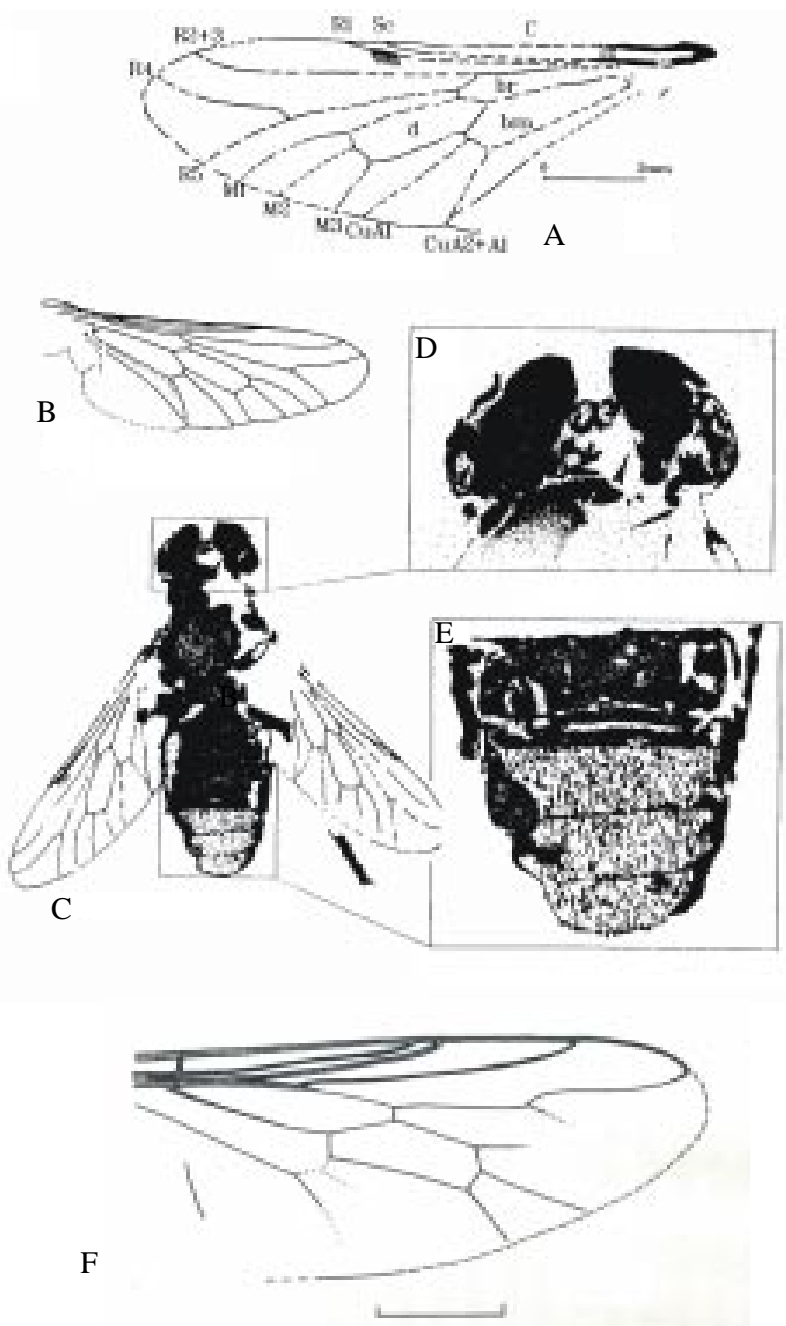

Fig. 2: Cratotabanus stenomyomorphus Martins-Neto \& Santos reproduced of Martins-Neto \& Santos (1994). A: left wing; B reconstruction the alar venation; C: general view; D: head detail; E abdomen chaetotaxy detail. All drawn of holotype. F: Cratotabanu. sp. n., reproduced of Grimaldi (1990).

to visit flowers (Pechuman \& Teskey 1981), although the emphatic affirmation that tabanid females are, necessarily, hematophagous (Pessôa \& Martins 1978), which coulc sound as an exclusivity for tropical species. However Martins (1940) had observed Neotropical female tabanids visiting flowers in Minas Gerais, Southeast Brazil (ir Verbenaceae, and also in "crisântemos" and orchids), bu never he had saw males visiting flowers (just resting ir the leaves). Also interesting from the Martins's observa. tions (1940) is the female (hemathophagous) ferociously feed on pigs, often on horses, but rarely on cows, (apar from humans). Chrysops have preference (after the Martin's observations) for the ear region of the mentionec animals. Chrysops rarely feeds on reptiles, such as the Brazilian crocodilid Jacaretinga (common in the State of Mato Grosso). Other Chrysops species feed on the back of horses, others on their legs, and others on their abdomen.
Despite the necessity of a rigorous taxonomical review, in the light of the modern systematic methods, the contribution of Martins (1940) revealed the presence of 9 genera and 42 species of Pangoniinae, and 12 genera and 52 species of Tabaninae (the most common genera, Chrysops, with 15 species and Tabanus, with 18 species), just in the Minas Gerais. Martins's main contributions are the pioneer observations on the biology and ecology of neotropical tabanids.

Going to the past, the source of warm blood from Santana Formation, cradle of Cratotabanus Martins-Neto, was scarce or insignificant. No mammals were found, at least until now, and just a single avian remain (a feather, Martins-Neto \& Kellner 1988) was found, indicating, at least, that the group was represented in the Araripe fauna. There was almost nothing for warm bloodfeeders at this time (at least in a stricto sensu, considering just mammals and aves as true warm-blooded animals).

The terrestrial vertebrates of the Araripe fauna were composed mainly of pterosaurs (one of the most important of the world, by the number of species represented as well as by the excellence of preservation), a few dinosaurs, turtles, a few lizards, crocodilians, and birds (an artistic view of the Araripe times is furnished in the Fig. 4). The climate was essentially tropical, optimal for tabanids and several groups of bloodsuckers, with transparent and oxygenated water available which was seasonally toxic with gas (Martins-Neto 1996).

Berner et al. (1983) concludes that the $\mathrm{CO}_{2}$ in the atmosphere during the Cretaceous times was greater than the presently. Similar conclusions were obtained by Berner and Landis (1988) through gas bubble inclusions in am-

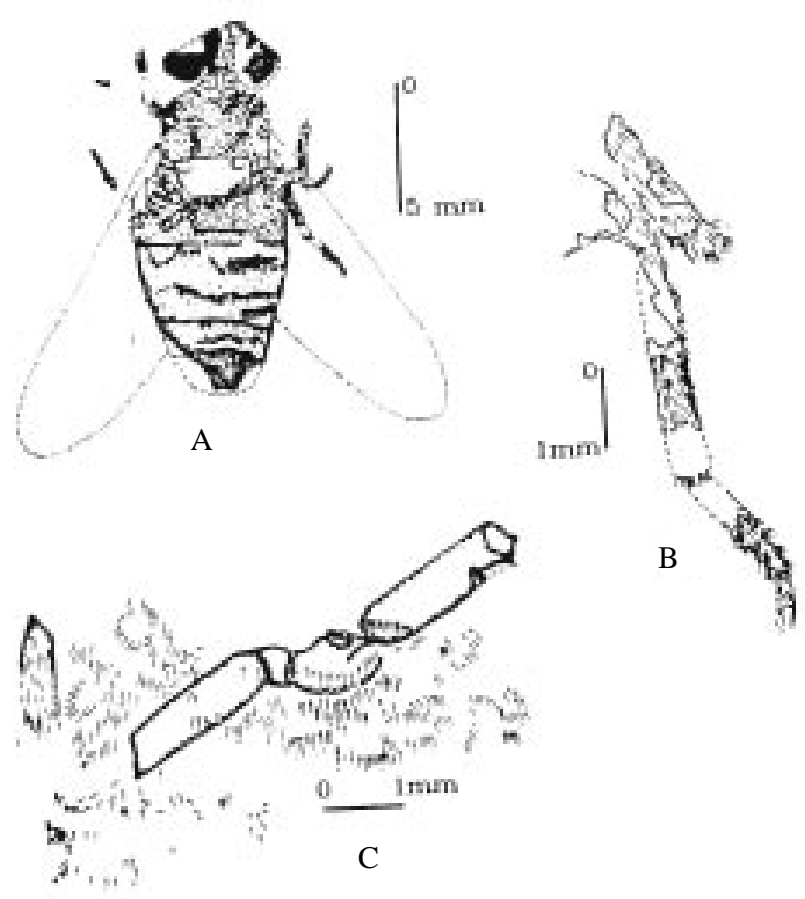

Fig. 3: Tabanus? tremembeensis Martins-Neto, reproduced of Martins-Neto (1997). A: general view; B: mesothoracic member detail; C: metathoracic member detail. 

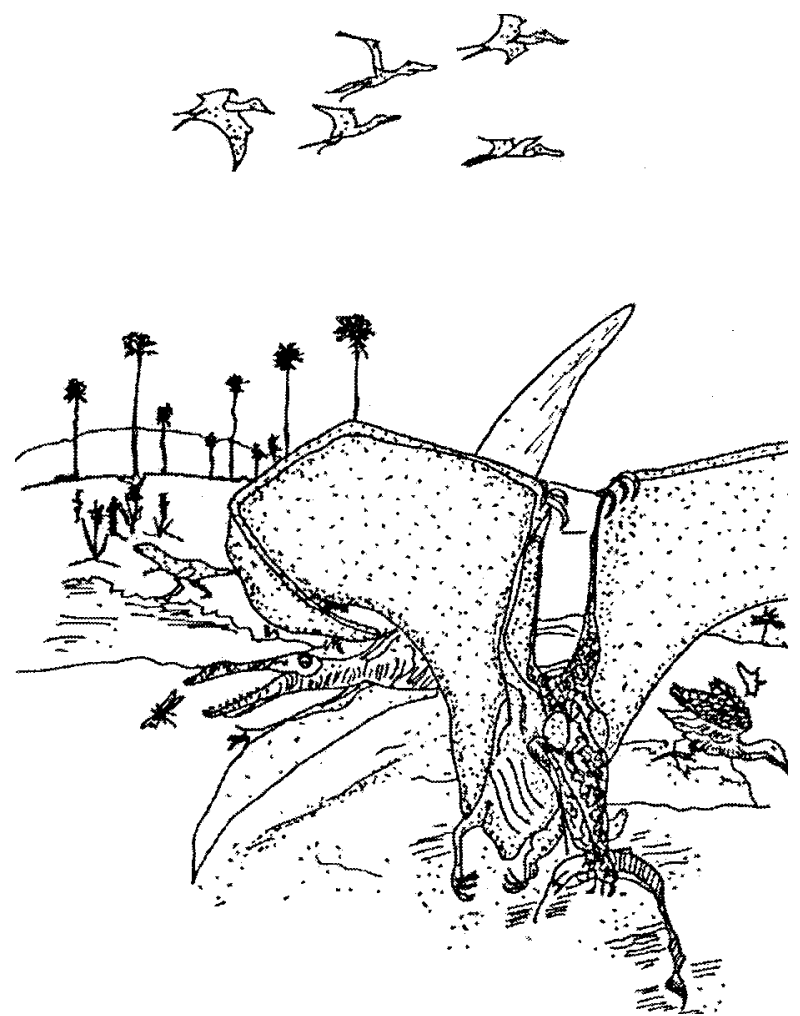

Fig. 4: artistic reconstruction of Araripe and its associated fauna, at the Lower Cretaceous times.

ber (Cretaceous from Cedar Lake, USA). On this theme, Emiliani et al. (1981) presents an interesting review of the maximal tolerances of temperature by the animals. The theme furnishes material for discussion. For example, it is debated whether or not the dinosaurs and pterosaurs were warm-blooded. Decades of discussion (see Baker 1986) proved, at least, that specific groups of dinosaurs could be warm-blooded and this could open the way earlier for the Cretaceous warm bloodfeeders.

Ponomarenko (1976) had found a flea-like insect preserved adhered in a pterosaur alar membrane, from the Siberian Jurassic. This occurrence absolutely does not prove that the insect was drinking warm-blood, but it is a good paleontological evidence for the beginning of the bloodsucking (cold or warm). For tabanids, the older evidence came from the Chinese Jurassic, with the pangoniine tabanid Palaepangonius eupterus Ren 1998, associated with flower-like structures including a complete body and an associated well-developed long proboscis, providing direct evidence for the mid-Mesozoic diversification within Tabanidae of subclades with nectaring mouthparts, as pointed by Ren (1998) and Labandeira (1998). This important find, however, doesn't furnish evidence for a possible tabanid bloodsucker at this time. No Tabaninae was found in Jurassic times, until now.

The panorama for the Tertiary is less debatable. There is no resistance to the idea that the tabanids were drinking warm blood from the ears of ungulates, which lived in herds, and several others groups of mammals. However, no direct paleontological evidence sustained this, until now. On the other hand, the record of tabanids known from several Eocene/Oligocene deposits in the world shows that it is highly probable that the group could have the same feeding habit as the present day tabaninids (including the fossil record of several genera living today).

THE DISEASES TRANSMISSION BY TABANIDS: WHEN THEY BEGAN? ARE THE TABANIDS REALLY GUILTY?

Several tabanid species in the extant fauna are vectors for disease-producing organisms that affect man and animals. Bacteria, viruses, rickettsiae, Protozoa, and filarial worms can be transmitted by them, causing such diseases as anthrax, tularemia, anaplasmosis, various forms of trypanosomiasis, $\mathrm{Q}$ fever, and filariasis (Pechuman $\&$ Teskey 1981). However, if tabanids are directly guilty for all these diseases, it is not consensual.

Tularemia was discovered in the United States, transmitted, as initially thought, by the tabanid Chysops discalis Williston. Today we know that the true culprit is an acarine, and this disease is not reported or is unknown for Brazil (Martins 1940), although several Neotropical tabanids have been found infected by similar acarines. Rickettisiae, for example, was recently addressed (Gray 1998) but again, no proof of responsibility for tabanidassociated diseases was directly demonstrated.

Several diseases are caused by nematodes. Blaxter et al. (1998) present a phylogenetical approach of the phylum Nematoda. They include considerations of trophical ecology such as: bacteriovore, algivore-omnivore-predator, fungivore, plant parasite, entomopathogen, invertebrate parasite, and vertebrate parasite. They concluded that animal parasitism arose independently at least four times, and plant parasitism three times. Strongylida is an exclusively vertebrate parasite group, as well as Ascaridina, Spirurida, Oxyurida, Rhabditidoidea, Strongyloididade and Trichocephalida. Exclusively entomopathogen are the groups heterorhabditids and Steinemematidae. Exclusively invertebrate parasites are the Rhigonematida and Mermithida. There is controversy about the phylogenetic tree and the position of the clades, and the relationships of the main clades and characters used (Voronov et al. 1998). But, for the scope of this paper, of all 55 branches of Blaxter et al. (1998), just two Rhigonematida and Mermithida - are exclusively invertebrate parasites. The former was represented in the fossil record, parasiting insects, including tabanids, as briefly documented below.

Voigt (1957) described an Eocene larval nematode encysted in a muscle tissue of a beetle. Larsson (1978) discussed parasitic nematodes within chironomids from the Baltic amber mermithids associated with dipterans, including an adult limoniid fly and a female mosquito. Taylor (1935) earlier summarized our knowledge of fossil nematodes, including a mermithid parasite within a German Baltic amber Oligocene chironomid (see also Boucot 1990). Statz (1944) presented mosquitoes and potential disease vectors (Culicidae in mammals) from de Germany Oligocene. Cockerell (1908) and Brues (1923) report Glossina (Muscidae) in beds of Oligocene age (fossils nematode trails 
was found earliear, in Eocene sediments - see Moussa 1970). This evidence suggests the possibility that trypanosome-ungulate, and other mammal relations may have been in existence for some time back into the past (Boutcot 1990). Dogiel (1964) and Grunin (1973) present Late Pleistocene warble-fly larvae (Cobboldia) occurring in the guts of mammoths from Siberia. Elephants today are also parasitized by these same flies.

Specifically for tabanids, the geological record does not furnish direct evidence until the Late Pliocene, when Grabenhorst reports mermithid nematodes infecting a fossil tabanid. The simple presence of fossil tabanids, and possible victims of their bite, falls in Boucot's (1990) Category 6: highly speculative, but the presence of nematodes in tabanids falls in the Boucot's (1990) Category 1: incontestable, the first and single for fossil tabanids.

\section{FINAL COMMENTS}

The fossil evidence furnishes us the following facts, conclusions, and speculations: (1) Flower-feeding tabanids (Pangoniinae) appear, at least, in the Upper Jurassic. This represents, in a phylogenetical sense, that bloodsucking (for tabanids) is a sinapomorphic condition, maybe attained later than the Lower Cretaceous (based on negative evidence rather than direct evidence); (2) Tabaninae tabanids appear, at least, in the Lower Cretaceous (based in negative evidence), earlier than the Aptian; (3) The presence of fossil tabanines in the Lower Cretaceous of Asia, South Africa, Brazil, Spain and England, in the light of the paleobiogeography, indicates that the group was represented earlier, at least in the beginning of the Cretaceous; (4) In a phylogenetical sense, cold bloodsucking precedes warm bloodsucking, indicating the Lower Cretaceous as the beginning for the bloodsuckers; (5) Warm bloodsucking in tabanids could have started in tropical regions, later than the mid-Cenozoic (speculative, based on negative evidence); (6) Disease transmission by tabanids is highly controversial. Presently, of all diseases attributable to tabanids, just nematoid infection is incontestable. The first paleontological evidence, however, dates from Upper Pliocene. For other dipteran groups the record is older, at least since the Eocene; (7) Tabanids are not guilty of all crimes (diseases) attributable to them. For several accusations there exist reasonable doubts.

\section{ACKNOWLEDGEMENTS}

To Dr Reginaldo Peçanha Brazil (Centro de Pesquisas René Rachou-Fiocruz), by the incentive, friendship, criticisms and suggestions; to Dr Deborah Rita Brunherotto (Sociedade Brasileira de Paleoartropodologia) for the inestimable help in pathology, physiology and by the fertile discussion on the theme; to Dr Conrad Chrystopher Labandeira (Smithsonian Institution, USA), a plant-arthropods interactions specialist, by suggestions, comments, and criticisms; to Dr Rob Coram (Maidstone Museum, UK) and Dr Ren Dong (National Geological Museum of China), by the friendship and help with reprints.

\section{REFERENCES}

Ansorge J 1994. Tanyderidae and Psychodidae (Insecta: Diptera) from the Lower Jurassic of northeastern Germany. Paläon Z 68: 199-210.
Bakker R 1986. The Dinosaurs Heresy: a Revolutionary View of Dinosaurs, Longman Scientific \& Technical, UK, 481 pp.

Berner RA, Landis GP 1988. Gas bubbles in fossil amber as possible indicator of the major gas compositions of ancient air. Science 239: 1406-1409.

Berner RA, Lasaga AC, Garrels RM 1983. The carbonate silica geochemical cycle and its effect on atmospheric carbon dioxide over the past 100 million years. Am J Sci 283: 641683.

Blaxter ML, De Ley P, Garey JR, Liu LX, Scheldeman P, Vierstraete A, Vanfieteren JR, Mackey LY, Dorris M, Frisse LM, Vida JT, Thomas WK 1998. A molecular evolutionary framework for the phylum Nematodea. Nature 392: 71-75.

Boucot AJ 1990. Evolutionary Paleobiology of Behaviour and Coevolution, Elsevier, UK 725 pp.

Bradley WH 1931. Origin and microfossils of the oil shale of the Green River Formation of Colorado and Utah. US Geol Surv Prof Pap 168: 1-58.

Brues CT 1923. Ancient insects fossils in amber and other deposits. Sci Mon 17: 289-304.

Cockerell TDA 1908. Fossil insects from Florissant, Colorado. Bull Am Mus Nat Hist 24: 59-69.

Cockerell TDA 1909. Fossil insects from Florissant, Colorado. Bull Am Mus Nat Hist 26: 67-76.

Cockerell TDA 1917. Some American fossil insects. Proc US National Museum 51(2146): 89-107.

Cockerell TDA 1921. Fossil arthropods in the British $\mathrm{Mu}-$ seum-VI. Oligocene insects from Gurnet Bay, Isle of Wight. Ann Mag Nat Hist 7: 453-80.

Coram R, Jarzembowski EA, Ross AJ 1995. New record of Purbeck fossil insects. Proc Dorset Nat Hist \& Archaeol Soc 116: 145-150.

Dogiel VA 1964. General Parasitology, Oliver and Boyd, Edinburg, $516 \mathrm{pp}$.

Emiliani C, Kraus EB, Shoemaker EM 1981. Sudden death at the end of the Mesozoic. Earth and Planetary Science Letters 55: 317-334.

Evenhuis NL 1994. Catalogue of Fossil Flies of the World (Insecta Diptera), Backhuys Publishers, Leiden, $305 \mathrm{pp}$.

Fairchild GB, Lane RS 1989. A second species of fossil Stenotabanus (Diptera: Tabanidae) in amber from the Dominican Republic. Fla Entomol 72: 630-632.

Grabenhorst H 1985. Eine Zweite Bremse (Tabanidae) zusammen mit ihrem Parasiten (Nematoda, Mermithoidae) aus dem Oberpliozän von Willershausen, Krs. Osterode Aufschluss 36: 325-328.

Gray MW 1998. Rickettsia, typhus and the mitochondrial connection. Nature 396: 109-110.

Grimaldi D 1990. Diptera. In DA Grimaldi, Insects from the Santana Formation, Lower Cretaceous of Brazil. Bull Am Mus Nat Hist 195: 164-183.

Grunin KY 1973. The first discovery of larvae of the mammoth bot fly Cobboldia (Mamontia, subgen. n.) russanovi sp. $\mathrm{n}$. (Diptera, Gasterophilidae). Entomol Rev 52: 165-169.

Hamilton KGA 1992. Lower Cretaceous Homoptera from the Koonwarra fossil bed in Australia, with a new superfamily and synopsis of Mesozoic Homoptera. Ann Entomol Soc Am 85: 426-430.

Heer O 1864. Die Urwelt der Schweiz, F. Schultheœ, Zürich, p. 289-496.

Hong Y-c 1982. Mesozoic Fossil Insects of Jiuquan Basin in Gansu Province, Geological Publ House, Beijing, 187 pp. (In Chinese).

Kovalev VG 1986. Infraorders Bibionomorpha and Asilomorpha. In: Insects in the early Cretaceous ecosystems of western Mongolia. Trudy Sovmest Sov-Mongol 
Paleontol Ekped 28: 125-154. (In Russian).

Labandeira CC 1998. How old is the flower and the fly? Science 280: 57-59.

Lane RSGO, Poinar Jr, Fairchild GB 1988. A fossil horsefly (Diptera: Tabanidae) in Dominican amber. Fla Entomol 71: 593-596.

Larsson SG 1978. Baltic amber - a Paleobiological Study. Entomograph 1, Scandinavian Science Press, Klampenborg, $192 \mathrm{pp}$.

Lewis DJ, Young DG, Fairchild GB, Minter DM 1977. Proposals for a stable classification of the phlebotomine sandflies (Diptera: Psychodidae). Syst Entomol 2: 319-332.

Lukashevich ED, Mostovski MB 2001.The dark past of the blood-suckers: history of blood-sucking in insects. In International Congress on Palaeontomolgy, 2, Krakow, Poland 2001. Abstracts, Institute of Systematics and Evolution of Animals, Polish Academy of Sciences, p. 41-42.

Maneval H 1936. Insectes fossiles des calcaires oligocènes de Ronzon (Le Puy). Ann Soc Linn Lyon 79: 23-37.

Martins AV 1940. Os Tabanídeos do Estado de Minas Gerais, Thesis, Faculdade de Medicina, UFMG, Belo Horizonte, 233 pp.

Martins-Neto RG 1996. New Mayflies (Insecta, Ephemeroptera) from the Santana Formation (Lower Cretaceous). Araripe Basin, Northeast Brazil. Rev Espan Paleontol 11: $54-70$

Martins-Neto RG 1997. Dípteros da Formação Tremembé, Bacia de Taubaté, Oligoceno do Estado de São Paulo. III - Família Tabanidae. Acta Geológica Leapoldensia 44: 51-57.

Martins-Neto RG 1999a. La Paleoentomofauna Brasileña. Estado actual del conocimiento. Rev Entomol Argentina 58: 71-85.

Martins-Neto RG 1999b. Dípteros da Formação Tremembé, Bacia de Taubaté, Oligoceno do Estado de São Paulo II Famílias Diastatidae, Empididae, Tipulidae e Mycetophilidae. Rev Univ Guarulhos, Ser. Geociências 4: 116129.

Martins-Neto RG, Kellner AWA 1988. Primeiro registro de pena na Formação Santana, Cretáceo Inferior da Bacia do Araripe, Nordeste do Brasil. An Acad Bras Ci 60: 61-68.

Martins-Neto RG, Santos JCK 1994. Um novo gênero e uma nova espécie de Mutuca (Insecta, Diptera, Tabanidae) da Formação Santana (Cretáceo Inferior), Bacia do Araripe, Nordeste do Brasil. Acta Geol Leopoldensia 39: 289-297.

Martins-Neto RG, Vieira FRM, Kucera-Santos JC, Fragoso LMC 1992. Dípteros (Insecta. Empidoidea) da Formação Trememhé, Bacia de Taubaté, Oligoceno do Estado de São Paulo. I - Família Hybotidae. Acta Geológica Leopoldensia, 36: $31-48$.

Maurice C 1882. Les Insectes Fossiles Spécialement d'Après les Travaux de Sir Samuel Scudder, Six-Horemans, Lille, 31 pp.

Melander AL 1947. Some fossil Diptera from Florissant, Colorado. Psyche 53: 43-48.

Morales CJ, Pimentel FZ 2001. The Diptera Order in the amber of Chiapas, Mexico. In International Congress on Palaeontomolgy, 2, Krakow, Poland 2001. Abstracts, Institute of Systematics and Evolution of Animals, Polish Acad- emy of Sciences, p. 47-48.

Mostovski MB 1998. A brief review of brachycerous flies (Diptera, Brachycera) in the Mesozoic, with descriptions of some curious taxa. Proceedings of the First Palaeoentomological Conference, Moscow, Bratislava, p. 103-110.

Moucha J 1972. Prehled fosilnich druhu ovádovitych (Insecta: Tabanidae). Cas Narod Mus 141: 28-29.

Moussa MT 1970. Nematode fossil trails from the Green River Formation (Eocene) in the Uinta Basin, Utah. J Paleontol 44: 304-307.

Pechumann LL, Teskey HJ 1981. Tabanidae. In JF McAlpine, Manual of Neartic Diptera, v. 1, Monograph 27, p. 463478.

Pessôa SB, Martins AV 1978. Parasitologia Médica, 10 ed., Guanabara Koogan, Rio de Janeiro, 883 pp.

Petrulevicius JF, Martins-Neto RG 2000. Checklist of South American Cenozoic Insects. Acta Geologica Hispanica 35: 135-147.

Piton L 1940. Paléontologie du gisement éocène de Menat (Puyde-Dôme) (Flore et faune). Mém Soc Hist Nat Auvergne 1: 1-303.

Ponomarenko AV 1976. Novie nasekomie iz Zabaikalia vozmozhni parazit letaooshikn yasherov. Paleontol $\mathrm{Zh} 3$ : 102-106.

Ren Dong 1998. Flower-associated Brachycera flies as fossil evidence for Jurassic angiosperm origin. Science 280: 8588.

Ribeiro GC, Krzeminski W 2000. New information on Limoniidae (Diptera: Tipulomorpha) from the Lower Cretaceous Santana Formation (Northeastern Brazil). Polskie Pismo Entomologiczne 69: 451-457.

Ribeiro GC, Martins-Neto RG 1999. A new Tipulidae (Insecta, Diptera) from the Santana Formation (Araripe Basin, Lower Cretaceous, Northeastern Brazil). In Simpósio sobre o Cretáceo do Brasil, 5, Serra Negra, SP, p. 207-212.

Sendder SH 1895. The Miocene insect-fauna of Oeningen, Baden. Geological Magazine 2: 116-122.

Scudder SH 1895. The Miocene insect-fauna of Oeningen, Baden. Geological Magazine 4: 116-122.

Statz G 1944. Neue dipteren (Nematocera) aus dem Oberoligozän von Rott. V. Familie Culiciden (steckmuecken). Palaeontographica 95: 108-121.

Swanson JR, Lewis SE 1993. Fossil insects of the Green River Formation. Occas Pap Paleobiol 7: 1-9.

Taylor AL 1935. A review of fossil nematodes. Proc Helminthol Soc Wash 2: 47-49.

Voigt E 1957. Ein parasitischer nematode in fossiler Coleopteren-Muskulatur aus der eozänen Braunkohle des Geiseltales bei Halle (Saale). Paläontol Z 31: 35-39.

Voronov DA, Panchin YuV, Spiridinov SE 1998. Nematode phylogeny and embryology. Nature 395: 28.

Vulcano MA 1985. Cretaceosimulium araripense gen. sp. nov. da Chapada do Araripe, Ceará, Brasil (Diptera Simuliidae). In Congresso Brasileiro de Zoologia, 12, Campinas, p. 107.

Zhang J-f 1993. Mesozoic gadflies (Insecta: Diptera). Acta Palaeontol Sinica 32: 662-672.

Zeller PC 1842. Dipterologische Beyträge. Zweyte Abtheilung. Isis (Oken's) 1842: 807-847. 